\title{
MODEL SENAM REMATIK SEBAGAI UPAYA PENINGKATAN AKTIFITAS FUNGSIONAL LANSIA DI PSTW PUSPAKARMA MATARAM
}

\author{
Mas'adah \\ Jurusan Keperawatan Mataram Poltekkes Mataram Kemenkes RI \\ Jl. Kesehatan V/10 Pajang Mataram \\ masadah_viky@yahoo.co.id
}

\begin{abstract}
ABSTRAK
Proses penuaan menyebabkan penurunan fungsi musculoskeletal seperti degenerasi, erosi, dan kalsifikasi tulang rawan dan kapsul sendi.Penurunan kemampuan muskuloskeletal akibatnya dapat menurunkan Range Of Motion (ROM) sehingga akan mempengaruhi lansia dalam melakukan aktivitas fungsional sehari-hari (ADL). Jenis penelitian ini quasy eksperiment yang bertujuan untuk melihat efektifitas senam rematik terhadap aktifitas fungsional lansia. Desain yang digunakan adalah one group pretest posttes. Populasinya adalah semua lansia yang menderita nyeri rematik yang tinggal di PSTW Puspakarma Mataram dengan teknik pengambilan sample menggunakan purposive sampling yaitu sebesar 26 responden. Variabel independen penelitian ini adalah model senam rematik dan dependennya aktifitas fungsional lansia. Data diambil dengan wawancara terstruktur dengan kuesioner dan observasi menggunakan instrumen Health Assessment Questionnaire (HAQ) kemudian dianalisa menggunakan Wilcoxon Sign Test. Hasil uji stasistik menunjukkan $\mathrm{p}=0,000$ artinya $\mathrm{p}<0,05$. Gerakan aktif pada senam rematik meningkatkan kerja otot-otot sekitar sendi sehingga mempercepat aliran darah dan menyebabkan nyeri berkurang. Model senam rematik memberikan pengaruh terhadap peningkatan aktifitas fungsional lansia yang tinggal di PSTW Puspakarma Mataram.
\end{abstract}

Kata kunci: Reumatik Arthritis, aktivitas fungsional lansia, Health Assessment Questionnaire

\begin{abstract}
The aging process causes decreased musculoskeletal function such as degeneration, erosion, and calcification of cartilage and joint capsule. Decreased musculoskeletal ability can decrease the Range Of Motion (ROM) so it will affect the elderly in performing daily functional activities $(A D L)$. This study used a quasy experimental one group pretest posttes design using the instrument Health Assessment Questionnaire (HAQ), The population were elderly people suffering from rheumatism living in Social Institution TresnaWerdha Puspakarma Mataramwith sampling technique using purposive sampling that is equal to 26 respondents. The independent variabel was exercises model of arthritis and the dependent variabel were improve the functional activity of the elderly. Data are taken by structured interview with questionnare and observation and analizedusing Wilcoxon Sign Test with significance level of $p<0,05$. The statistic revealed that $p=0,000$ for functional activity of the elderly. This active movement in rheumatic arthritis increases the work of the muscles around the joints thus accelerating blood flow and causing less pain. Exercises model of arthritis has effect to improve the functional activity of the elderly.
\end{abstract}

Keywords: Artritis rheumatism, Functional Activity of the elderly, Health Assessment Questionnaire

\section{PENDAHULUAN}

Proses penuaan menyebabkan penurunan fungsi musculoskeletal seperti degenerasi, erosi, dan kalsifikasi tulang rawan dan kapsul sendiserta menyebabkan penurunan fungsi imun selular seperti meningkatnya kegiatan peradangan di sendi $^{5}$. Keterbatasan pergerakan dan berkurangnya pemakaian sendi dapat memperparah kondisi tersebut ${ }^{14}$. Penurunan kemampuan muskuloskeletal dapat menurunkan Range of Motion (ROM) sehingga akan mempengaruhi lansia dalam melakukan aktivitas kehidupan sehari-hari (activity daily living atau ADL). 
Aktifitas seseorang tidak lepas dari ketidakadekuatan sistem persarafan dan musculoskeletal. Diantaranya dalam sistem saraf, lansia mengalami penurunan koordinasi dan kemampuan dalam melakukan aktivitas sehari-hari. Hal ini menyebabkan seseorang dengan usia lanjut rentan terhadap penyakit khususnya penyakit kronis seperti hipertensi, artritis dan diabetes. Penurunan fisik ini dapat dilihat dari kemampuan fungsional lansia, terutama kemampuan lanjut usia untuk melakukan aktivitas kehidupan sehari-hari seperti berpakaian, buang air besar atau kecil, makan, minum, berjalan, tidur dan mandi. Dari kemampuan melakukan aktifitas tersebut dapat dinilai apakah lanjut usia mandiri atau bergantung pada orang lain ${ }^{9}$.

Hasil studi pendahuluan yang dilakukan oleh peneliti melalui wawancara langsung dengan petugas kesehatan di PSTW Puspa Karma Mataram terdapat 77 orang lansia yang tinggal di Panti dengan kriteria umur lebih dari 60 tahun sampai 90 tahun dan terdapat lebih dari 50\% lansia mengeluh nyeri sendi dan rematik sehingga untuk melakukan kegiatan fungsional seharihari banyak dibantu oleh petugas kesehatan, sementara itu banyak sekali program lansia yang harus diikuti oleh mereka namun karena terdapat keluhan nyeri sendi menyebabkan hanya sebagian kecil saja yang tetap aktif mengikuti kegiatan yang diprogramkan dari panti. Program olahraga yang sudah dijalankan secara rutin di PSTW Puspa Karma Mataram adalah senam lansia yang merupakan salah satu program unggulan dari program pelayanan harian lanjut usia (PHLU) yang dilaksanakan seminggu dua kali secara rutin dengan mengundang para lansia dari luar panti namun hanya sekitar 20 orang lansia saja yang rutin mengikuti kegiatan senam lansia tersebut dikarenakan membutuhkan fisik yang kuat. Senam rematik sendiri belum pernah dilakukan atau diberikan kepada para lansia yang terdeteksi menderita rematik di Panti Werdha Puspa Karma Mataram padahal teknik pelaksanaan senam rematik mudah dan tidak membutuhkan tenaga yang berlebihan sehingga lansia mampu mengikuti dengan baik.

Hasil penelitian yang pernah dilakukan oleh Lestari dkk (2014) di Panti Werdha Ilomata Kota Gorontalo terhadap lansia yang mengalami nyeri rematik setelah diberikan senam lansia menunjukkan hasil skala nyeri sendi lansia mengalami penurunan dengan skala sedang $83,33 \%$ dan skala ringan $16,67 \%$. Sementara itu hasil penelitian yang dilakukan oleh Ulliya dkk pada lansia dengan gangguan fleksibilitas sendi lutut setelah dilakukan latihan ROM terdapat peningkatan rerata fleksibiltas sendi lutut kanan dan kiri pada pengukuran kedua (setelah 3 minggu latihan ROM) \& ketiga (setelah 6 minggu latihan ROM).

Upaya mempertahankan dan meningkatkan status fungsional lansia dapat dilakukan tindakan preventif dan promotif yang berupa latihan fisik guna meningkatkan kebugaran. Lansia dengan rematik dapat ditingkatkan status fungsionalnya dengan mengurangi nyeri dan mencegah penyakit rematik menjadi lebih parah dengan menggunakan metode gerak tubuh yang lebih dikenal dengan senam rematik. Senam ini berkonsentrasi pada gerakan sendi sambil meregangkan dan menguatkan ototnya karena otot-otot inilah yang membantu sendi untuk menopang tubuh (DepKes RI, 2013). Dengan melakukan senam rematik diharapkan kualitas hidup lansia meningkat sehingga lansia dapat melakukan aktifitas fungsional dengan maksimal dan tidak menjadi beban bagi orang lain dan dalam hal ini peneliti tertarik untuk melakukan penelitian tentang upaya peningkatan aktifitas fungsional lansia melalui senam rematik di PSTW Puspa Karma Mataram.

\section{BAHAN DAN METODE}

Jenis penelitian ini quasy eksperiment yang bertujuan untuk melihat efektifitas senam rematik yang dirancang oleh peneliti. Desain penelitian ini adalah One group Pretest-Posttest design, Intervensi yang diberikan adalah model senam rematikpada kelompok perlakuan. Populasi dalam penelitian ini adalah semua lansia penderita rematik di PSTW Puspakarma Mataram. Sampel penelitian ini yaitu lansia penderitarematik di PSTW Puspakarma yang memenuhi kriteria inklusi. Kriteria inklusi sebagai berikut: lansia bersedia menjadi subyek penelitian, bersedia mengikuti senam rematik sebanyak 9x latihan, tidak mempunyai penyakit gangguan kardiovaskuler berat, lanisa dengan nyeri sendi dan tidak sedang mengikuti senam 
atau olahraga lansia lain. Dalam penelitian ini, cara pengambilan sampel yang digunakan adalah purposive sampling.

Variabel independent yaitu model senam rematik. Terapi senam rematikdilakukan selama3 minggu dengan rincian 3x dalam seminggu secara berturutturut dengan total pelaksanaan sebanyak 9x latihan senam. Variabel dependent yaituaktifitas fungsional lansia yang diukur dengan menggunakan lembar instrumen Health assessment Questionare (HAQ). Waktu dan Tempat Penelitian di PSTW Puspakarma Mataram. Waktu pelaksanaan penelitian pada bulan Agustus - September 2016 yang diawali dengan kegiatan birokrasi perijinan sesuai dengan prosedur yang telah ditetapkan.

Data dalam penelitian ini dikumpulkan dengan menggunakan lembar instrumen Health Assessment Questionare.Dalam rancangan ini seluruh responden dilakukan pengukuran kemampuan aktivitas fungsionalnya dengan HAQ sebelum diberikan senam rematik, kemudian responden diajarkan cara melakukan senam rematik lalu dianjurkan mencoba sendiri. Setelah responden benarbenar mampu maka responden diberi intervensi dengan senam rematik selama 3 minggu dengan rincian $3 x$ setiap minggunya oleh peneliti dengan berselang 2 hari jarak pemberian senamnya dengan total pelaksanaannya 9x senam. Senam dilakukan secara bersama-sama yang dipimpin oleh peneliti langsung dengan didampingi oleh enumarator dari PSTW Puspakarma Mataram pada sore hari di tempat yang sudah ditentukanseperti di depan Poliklinik atau di depan Masjid PSTW Puspakarma Mataram. Bagi responden yang tidak mampu melakukan bersama-sama maka dilakukan oleh enumerator di dalam kamar dimana mereka tinggal. Setelah responden selesai melakukan senam rematik selama 3 minggu berturut-turut maka responden dilakukan pengukuran aktifitas fungsional sehari-harinya menggunakan instrumen HAQ kembali yang terdiri atas 8 komponen kegiatan yang masing-masing komponen berisi 2 sampai 3 kegiatan. Pengukuran Posttest dilakukan pada hari ke 2 setelah selesai dilakukan semua intervensi senam rematik melalui observasi dan menanyakan langsung kepada responden, kemudian hasilnya di skoring dan dikategorikan lalu dibandingkan antara sebelum dan sesudah diberikan perlakuan.

\section{HASIL}

Hasil analisis univariat mendapatkan rata-rata kelompok umur responden lansia terbesar adalah kelompok umur 61-70 tahun sebanyak 14 orang lansia (54\%).Kelompok responden dengan jenis kelamin terbanyak adalah perempuan dengan prosentase $65 \%$ atau 17 orang lansia dan sisanya adalah lakilaki yaitu 35\%.Distribusi Responden Berdasarkan Riwayat penyakit Dahulu terbanyak adalah menderita hipertensi dengan prosentase sebesar $19 \%$ atau 5 orang lansia. Dan distribusi responden berdasarkan riwayat pekerjaan adalah sebanyak 19 orang atau $58 \%$ responden.

Analisa bivariat aktifitas fungsional lansia sebelum dan setelah diberikan intervensi model senam rematik menggunakan uji Wilcoxon Signed Rank Test dapat digambarkan pada tabel 1 dibawah ini

Tabel 1 Hasil Analisa Statistik Model Senam Rematik terhadap upaya peningkatan aktifitas fungsional lansia

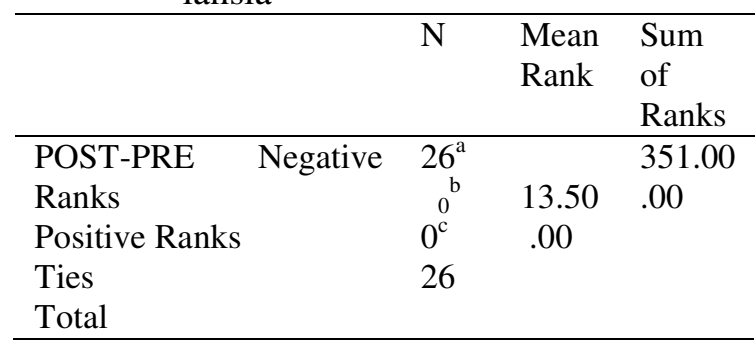

Test Statistic

\begin{tabular}{ll}
\hline & POST - PRE \\
\hline $\mathrm{Z}$ & -4.469 \\
Symp.Sig. (2 -tailed) & .000 \\
\hline
\end{tabular}

Dari tabel 1 output ranks menunjukkan perbandingan aktifitas fungsional lansia sebelum dan sesudah diberikan model senam rematik, terdapat 26 responden dengan hasil lebih rendah sesudah intervensi daripada sebelum intervensi dengan kata lain nilai terendah yang dimiliki 26 responden menunjukkan adanya peningkatan dari ketidakmampuan melakukan aktifitas fungsional sesudah dilakukan senam rematik. 
Berdasarkan hasil dari perhitungan Wilcoxon Signed Rank Test, maka nilai Z yang didapat sebesar $-4,469$ dengan $p$ value $=$ $0,000 \quad(p<0,05)$ maka keputusan hipotesis adalah tolak hipotesis nol (H0) dengan demikian disimpulkan terdapat perbedaan skor yang signifikan terhadap perlakuan sebelum dan sesudah senam rematik atau terdapat peningkatan aktifitas fungsional lansia yang bermakna setelah dilakukan senam rematik.

\section{PEMBAHASAN}

Berdasarkan hasil penelitian ini didapatkan bahwa pada saat dilakukan posttest pada 8 komponen kegiatan dengan jumlah keseluruhan ada 20 kegiatan aktifitas fungsional lansia maka terdapat beberapa kegiatan yang mengalami peningkatan cukup signifikan sepertikegiatan berpakaian, bangun dari kursi, bangun dari tempat tidur, memotong ikan, membawa gelas dengan air terisi penuh, berjalan dilantai, membersihkan halaman dan kebersihan diri seperti mandi dan memakai handuk termasuk pada kategori kemampuan tidak mengalami kesulitan. Sementara itu pada beberapa kegiatan lain juga dominan mengalami peningkatan tetapi berada pada kategori sedikit mengalami kesulitan seperti naik tangga, berjalan $1 \mathrm{~kg}$, kekamar kecil untuk $\mathrm{BAK} / \mathrm{BAB}$, angkat berat, berbelanja, membuka botol minuman dan membungkuk mengambil barang, hal ini sesuai dengan teori Priyatno (2014) bahwa nyeri sendi pada umumnya terjadi pada sendi penopang beban tubuh dan nyeri lebih terasa pada saat bergerak dan terasa bertambah hebat terutama pada pingggul, lutut, dan jari -jari. Penurunan kemampuan muskuloskeletal dapat menurunkan Range Of Motion (ROM) sehingga akan mempengaruhi lansia dalam melakukan aktivitas kehidupan sehari-hari (activity daily living atau ADL). Proses menua menyebabkan penurunan produksi cairan sinovial pada persendian dan tonus otot, kartilago sendi menjadi lebih tipis dan ligamentum menjadi lebih kaku serta terjadi penurunan kelenturan (fleksibilitas), sehingga mengurangi gerakan persendian. Kekakuan dapat disebabkan oleh adanya kalsifikasi pada lansia yang akan menurunkan fleksibilitas sendi. Sendi lutut mempunyai struktur ligamentum yang kuat karena berfungsi sebagai penopang tubuh, hal ini juga akan mempengaruhi kemungkinan terjadinya kekakuan pada sendi lutut ${ }^{14}$.

\section{KESIMPULAN}

Berdasarkan hasil penelitian yang telah dilakukan, dapat disimpulkan :

1. Aktifitas fungsional lansia di PST Puspakarma Mataram sebagian besar pada waktu pre test dikategorikan mengalami sedikit kesulitan dan beberapa kesulitan

2. Aktifitas fungsional lansia di PSTW Puspakarma Mataram sebagaian besar pada waktu post test mengalami peningkatan aktifitas fungsional

3. Model senam rematik memberikan pengaruh dalam peningkatan aktifitas fungsional lansia.

\section{SARAN}

Saran yang dapat dipertimbangkan dan bermanfaat untuk menerapkan model senam rematik pada lansia terutama di PSTW Puspakarma Mataram terhadap aktifitas fungsional sehari-hari lansia adalah sebagai berikut :

1. Memberikan informasi dari hasil penelitian bahwa senam rematik cukup efektif untuk mengurangi nyeri rematik pada lansia.

2. Memberikan informasi tentang model senam rematik sebagai salah satu metode dalam meningkatkan aktifitas fungsional pada lansia terutama mereka yang tinggal di Panti Sosial Tresna Werdha.

3. Sebagai data dasar atau pembanding untuk peneliti selanjutnya.

\section{DAFTAR PUSTAKA}

1. Adhitya Putra Widyantoro, Ika RosdianaMinidian Fasitasari. (2012). Hubungan antara Senam Lansia dan Range of Motion (ROM) Lutut pada Lansia Studi Observasional pada Lansia di Kecamatan Pedurungan. Semarang. Sains Medika.4(1):39-45)

2. Afiani, S. R. (2014). Pengaruh Terapi Aktivitas Senam Ergonomis terhadap Penurunan Skala Nyeri Sendi pada Lanjut Usia dengan Degeneratif Sendi di Wilayah Kerja Puskesmas Kasihan II Bantul Yogyakarta. Jurnal 
Keperawatan.

Universitas

Muhammadiyah Yogyakarta.

3. Agustina N.R (2012). Perempuan Dua

Kali Lebih Beresiko Rematik

Dibanding Pria. Artikel Tribun

Kesehatan.diakses tanggal 27

Nopember 2016 pada

mtribunnews.com.

4. Archenholtz (2008). Validity and reliability of the instrument Performance and satisfaction in Activities of Daily Living (PS-ADL) and its clinical applicability to adults with rheumatoid arthritis, Scandinavian Journal of Occupation Therapy. P;15:13-22

5. Darmojo, Boedhi, R.Martono,Hadi.H. (2010). Buku Ajar Geriatri (Ilmu Kesehatan Lanjut Usia).Balai Penerbit FK UI: Jakarta

6. Depkes RI (2013). Pedoman Pembinaan Kesehatan Usia Lanjut Bagi Petugas Kesehatan, Depkes RI; Jakarta.

7. Kuntaraf, J dan Kuntaraf, K. (1992). Olahraga Sumber Kesehatan.

Bandung: Advent Indonesia

8. Kusmana. (2006). Olahraga bagi Kesehatan Jantung. Jakarta: Fakultas Kedokteran Universitas Indonesia.

9. Kushariyadi (2011). Asuhan Keperawatan Pada Klien Lanjut Usia. Jakarta: Salemba Medika.

10. Lestari, Boekoesoe, \& Duhalu. (2014). Pengaruh senam lansia terhadap penurunan intensitas nyeri pada lansia dengan Arthritis Reumatoid di Panti Tresna Werdha Ilomata Kota Gorontalo. FIKK Universitas Negeri Gorontalo. Diakses 14 April 2016 pada http://6133-10055-1-SM.pdf.

11. Maryam, R Siti. (2008). Mengenal Usia Lanjut dan Perawatannya. Jakarta: Salemba Medika

12. Ramy Dr Fries JF. Sigh G.in BSpilker (1996). Quality of life and pharmacoleconomics in clinical Trials, $2^{\text {nd }}$ ed, The health Assessment Questionnare 1995-status and review. Philadelphia: Lippincott-Raven Pub., 1996. P.227-237

13. Suhendriyo (2014). Pengaruh Senam Rematik terhadap nyeri pada lutut. Jurnal Terpadu Ilmu Kesehatan, Volume 3, No 1, Mei 2014, hlm 1-6

14. Tortora dan Grabowski (2003). Principles of anatomy and physiology. (9th ed.). Toronto: John Wiley \& Sons, Inc

15. Ulliya U, Soempeno B, Kushartanti W (2007). Pengaruh latihan Range of Motion (ROM) terhadap fleksibilitas Sendi Lutut pada Lansia di Panti Werda Wening Wardoyo Ungaran. Media Ners ; Volume 1, Nomor 2, Oktober 2007, hlm 49.

16. Wolfe F. (1989). A brief clinical health assessment instrument:

CLINHAQ. Arthritis Rheum. 1989; 32 (suppl): $\mathrm{S} 9$ 